Ann. Biol. anim. Bioch. Biophys., 1979, 19 (2 A), 355-365.

\title{
The effect of exogenous oxytocin on estrous cycle length and corpus luteum lysis in ewes
}

\author{
par I. HATJIMINAOGLOU, T. ALIFAKIOTIS, N. ZERVAS \\ Animal Husbandry Department, School of Agriculture ond Forestry, \\ University of Thessaloniki, Greece.
}

Summary. The effect of exogenous oxytocin on estrous cycle length and corpus luteum lysis was investigated. A total of 111 ewes was used in 4 separate experiments. The results of experiment 1 showed no significant reduction of estrous cycle length of oxytocin-treated ewes ; however, 2 out of 8 ewes experienced new estrus 6 days after the initial one. The results of experiment 2 clearly showed $(P<0.05)$ the luteolytic property of 50 IU of oxytocin when administered at days 1 to 7 of the cycle. The results of experiments 3 and 4 showed that the destruction of the endometrium or uterine ablation (hysterectomy) negated the luteolytic property of oxytocin. It was concluded that the administration of $50 \mathrm{IU}$ of oxytocin daily from days 1 to 7 of the cycle resulted in luteal lysis in ewes and that the luteolytic action of oxytocin was mediated through the endometrium.

\section{Introduction.}

Armstrong and Hansel (1959) originally reported that oxytocin administered during the first third of the estrous cycle in cows reduced the cycle length to 8 to 12 days. Afterwards many investigators (Hansel, 1959 ; Cameroun and Fosgate, 1964 ; Hansel and Wagner, 1960 ; Labhsetwar ef al, 1964 ; Anderson ef al., 1965 ; Ginther ef al., 1967 ; Donalson and Takken, 1968 ; Carlson and Black, 1969 ; Donalson, 1969 ; Harms and Malven, 1969 ; Hoppe et al., 1969 ; Auletta ef al., 1972 ; Milvae ef al., 1976 ; Newcomb ef al., 1977) studied the luteolytic effect of exogenous oxytocin in cattle to determine the mechanism of this hormonal action. Most of these authors reported that the uterus implicated as a target organ of oxylocin action, thus suggesting a local utero-ovarian mechanism (Armstrong and Hansel, 1959 ; Hansel, 1959 ; Hansel and Wagner, 1960 ; Labhsetwar et al., 1964 ; Anderson ef al., 1965 ; Black and Duby, 1965 ; Ginther et al., 1967 ; Auletta et al., 1972 ; Newcomb et al, 1977), although some investigators (Cameroun and Fosgate, 1964 ; Donalson et al., 1965 ; Donalson and Taken, 1968 ; Carlson and Black, 1969 ; Donalson, 1969 ; Harms and Malven, 1969) found indications of hypophyseal-pituitary-gonadal axis involvement by altering the function of pituitary and ovary. In general, most of the work so far has been carried out on cattle, and it seems that cows are the only domestic animals in which the administration of oxytocin early in the estrous cycle inhibits corpus luteum deve- 
lopment and shortens the estrous cycle. The object of the present investigation was to determine the effect of exogenous oxytocin on the length of the estrous cycle and on lysis of the corpus luteum in ewes and to interpret the possible mechanism of this hormonal action.

\section{Material and methods.}

Four separate experiments were carried out in the present study.

Experiment 1. - Twenty-four cycling ewes of a local milking breed (Karagouniko) were synchronized subcutaneous silicone rubber implants containing $375 \mathrm{mg}$ of progesterone and left in place for 14 days. As the ewes came into estrus, they were individually identified by numbered plastic eartags and randomly assigned to 3 experimental groups of 9 animals each. Estrus was detected by vasectomized rams and the presence of corpora lutea was ascertained by laparotomy on day 2 (day $0=$ estrus) of the cycle. The ewes in group 1 received an intramuscular injection of $50 \mathrm{IU}$ of oxytocin daily from days 1 to 7 of the estrous cycle; the animals in group 2 received the same injection daily from days 8 to 14 . The ewes in group 3 received no treatment and served as controls. All ewes were kept with 2 vasectomized rams and checked for estrus 3 times daily for a period of 25 days. Table 1 shows the overall experimental design.

TABLE 1

Experimental design

\begin{tabular}{lccc}
\hline Treatment & $\begin{array}{c}\text { Days } \\
\text { injected }\left({ }^{1}\right)\end{array}$ & $\begin{array}{c}\text { Day of } \\
\text { laparotomy }{ }^{(2)}\end{array}$ & No ewes $\left(^{(3)}\right.$ \\
\hline Oxytocin 50 IU $\left(^{(4)} \ldots \ldots \ldots \ldots\right.$ & $1-7$ & 2 & 8 \\
Oxytocin 50 IU ${ }^{(4)} \ldots \ldots \ldots \ldots$ & $8-14$ & 2 & 8 \\
Controls $\left(^{(5)} \ldots \ldots \ldots \ldots \ldots\right.$ & - & 2 & 8 \\
\hline
\end{tabular}

(1) Day $0=$ day of estrus.

(2) For ascertaining ovulation.

(3) All ewes were synchronized using progesterone implants for 14 days.

$\left({ }^{4}\right)$ Intramuscular daily injections.

(5) No treatment.

Experiment 2. - A total of 30 ewes were used in this trial to further examine the luteolytic effect of exogenous oxylocin on the corpus luteum itself. As in experiment 1 , the ewes were synchronized and divided into 3 equal groups. The ewes in groups 1 and 2 were treated with oxytocin, as in the first experiment, while the ewes in group 3 received no treatment and served as controls. Estrus was detected by vasectomized rams and ascertained by laparotomy at day 2 of the estrous cycle. All the ewes of 
the 3 groups were autopsied on day 13 of the cycle and the corpora lutea were carefully dissected and weighed. Table 2 shows the overall experimental design.

TABLE 2

Experimental design

\begin{tabular}{lcccc}
\hline Treatment & $\begin{array}{c}\text { Days } \\
\text { injected }\left({ }^{1}\right)\end{array}$ & $\begin{array}{c}\text { Day of } \\
\text { laparotomy }\left({ }^{1}\right)\end{array}$ & $\begin{array}{c}\text { Day of } \\
\text { slaughter }\left({ }^{(1)}\right.\end{array}$ & $\begin{array}{c}\text { No } \\
\text { ewes }\left({ }^{2}\right)\end{array}$ \\
\hline Oxytocin 50 IU $\left(^{3}\right) \ldots \ldots \ldots$ & $1-7$ & 2 & 13 & 10 \\
Oxytocin 50 IU $\left(^{3}\right) \ldots \ldots \ldots$ & $8-14$ & 2 & 13 & 10 \\
Controls $\left({ }^{4}\right) \ldots \ldots \ldots \ldots$ & - & 2 & 13 & 10 \\
\hline
\end{tabular}

(1) Day $0=$ day of estrus.

(2) All ewes were synchronized using progesterone implants for 14 days.

(3) Intramuscular daily injections.

(4) No treatment.

Experiment 3. - This experiment investigated corpus luteum functioning under the action of exogenous oxytocin and the possible luteolytic mechanism of this hormone. A total of 33 ewes were synchronized using progesterone implants for 14 days and 1000 IU of PMS on the day of implant removal ; they were divided into 3 equal groups as they came into estrus. Vasectomized rams were used to defect estrus. The ewes of groups 1 and 2 were given an intramuscular injection of $50 \mathrm{IU}$ of oxytocin daily from days 1 to 7 of the estrous cycle, while ewes of group 3 received no treatment and served as controls. All ewes were laparotomized on day 3 , reproductive tracts were exteriorized and the uteri of group 1 ewes were infused with $20 \mathrm{cc}$ of a 10 p. 100 phenol solution (endometrium-modified group); the uteri of group 2 ewes infused with $20 \mathrm{cc}$ of physiological saline solution (endometrium-intact group). Control ewes received no intrauterine infusion. The intrauterine infusion of a 10 p. 100 phenol solution was found (Alifakiotis, 1973 ; Foote ef al., 1974 ; Alifakiotis, 1977) to destroy the secretory portion of the endometrium in sheep and to cause luteal maintenance. All ewes were autopsied on day 12 of the cycle. The genital tracts were dissected and specimens from the two uterine horns of each ewe were removed and further processed using the standard hematoxylin-eosin staining method for determining the degree of endometrial destruction. The corpora lutea were removed, weighed and frozen for subsequent progesterone analysis. The progesterone content of the corpora lutea was extracted and measured using radioimmunoassay.

\section{Extraction and radioimmunoassay of progesferone.}

We used the basic procedure described by Louis and Kittok (1973) with some minor modifications of corpus luteum progesterone extraction (Svejda and Foote, 1973). Each corpus luteum was homogenized in $3 \mathrm{ml}$ of physiological saline solution using a glass grinder. To account for procedural loss, $25000 \mathrm{cmp}$ (40000 dmp) of ${ }^{3} \mathrm{H}-1 \mathrm{a}, 2 \mathrm{a}$, -progesterone were added for recovery. The luteal emulsion was extracted twice using $5 \mathrm{ml}$ of analytical grade diethyl ether for $30 \mathrm{sec}$. each time, and the pooled 
extracts were washed with $1 \mathrm{ml}$ of deionized water. The tubes containing the washed extracts were then stored at $-20^{\circ} \mathrm{C}$ for $1 \mathrm{hr}$. to freeze the aqueous phase. The extracts destined for radioimmunoassay were decanted into $10 \mathrm{ml}$ volumetric flasks and dried down under nitrogen at $40^{\circ} \mathrm{C}$; the flasks were then made up to $10 \mathrm{ml}$ by adding methyl alcohol. Aliquots of $1 \mathrm{ml}$ volume were counted for procedural loss. A $10 \mathrm{ml}$ aliquot taken from the first volumetric flask placed in a second $10 \mathrm{ml}$ volumetric flask. The extract in the second flask was made up to $10 \mathrm{ml}$ by again adding methyl alcohol. Aliquots of $0.1 \mathrm{ml}$ were taken from these flasks, placed in triplicate glass culture tubes $(12 \times 75 \mathrm{~mm})$ and then dried down under nitrogen at $40^{\circ} \mathrm{C}$.

Normal rabbit sera, diluted 1 : 400 with $0.05 \mathrm{M}$ EDTA (or 0.1 p. $100 \mathrm{Knox}$ gelatin) in $0.01 \mathrm{M}$ phosphate buffered saline, were used to dilute the antibody to $1: 4500$. $0.2 \mathrm{ml}$ of the antibody was added to each tube, worlexed for $10 \mathrm{sec}$. and allowed to incubate at room temperature for $30 \mathrm{~min}$. Two hundred microliters of $0.1 \mathrm{p} .100$ gelatin in $0.01 \mathrm{M}$ phosphate buffered saline, containing $45000 \mathrm{dpm}$ of ${ }^{3} \mathrm{H}-1 \mathrm{a}, 2 \mathrm{a}$, -progesterone (New-England Nuclear, $96 \mathrm{c} / \mathrm{m}$ ) were added to each tube. The contents of the tubes were mixed for $5 \mathrm{sec}$. and incubated for 12 to $18 \mathrm{hrs}$. at $5 \circ \mathrm{C}$.

To separate bound and free progesterone, $1.0 \mathrm{ml}$ of $0.5 \mathrm{p} .100$ dextran T70 (Pharmacia, Uppsala, Sweden) and 0.25 p. 100 carbon decolorizing neutral norit (Fisher Scientific Co.) in deionized water were added to each tube. The contents were mixed, incubated in an ice bath for $10 \mathrm{~min}$. and then centrifuged at $2500 \mathrm{~g}$ for $10 \mathrm{~min}$. at $5{ }^{\circ} \mathrm{C}$. A $0.5 \mathrm{ml}$ aliquot of the supernatant fluid was diluted with a liquid scintillation fluid (Omnifluor) for quantification of radioactivity in a liquid scintillation spectrometer (Beckman, model 133). For comparison among assays, standard sera with high and low progesterone, and extracts from blank extraction tubes were assayed with each set of unknown luteal extracts. The data from the assay, based on standard curves, were reduced by computer. Table 2 shows the overall experimental design.

TABLE 3

Experimental design

\begin{tabular}{|c|c|c|c|c|c|}
\hline \multicolumn{2}{|c|}{ Treatments } & \multirow{2}{*}{$\begin{array}{l}\text { Day of } \\
\text { injection }\left(^{2}\right)\end{array}$} & \multirow{2}{*}{$\begin{array}{l}\text { Day of laparotomy } \\
\text { and infusion }\left({ }^{2}\right)\end{array}$} & \multirow{2}{*}{$\begin{array}{c}\text { Day of } \\
\text { slaughter }\left({ }^{2}\right)\end{array}$} & \multirow{2}{*}{$\begin{array}{c}\text { No. } \\
\text { ewes } \\
\left({ }^{3}\right)\end{array}$} \\
\hline Injection & Infusion (1) & & & & \\
\hline Oxytocin 50 IU $\left(^{(4)}\right.$ & $\begin{array}{l}10 \text { p. } 100 \text { phe- } \\
\text { nol. }\end{array}$ & $1-7$ & 2 & 12 & $11(5)$ \\
\hline Oxytocin 50 IU (4) & $\begin{array}{l}\text { Phys. saline } \\
\text { solution }\end{array}$ & $1-7$ & 2 & 12 & $11\left(^{\circ}\right)$ \\
\hline Controls $(?) \ldots \ldots$ & - & - & 2 & 12 & 11 \\
\hline
\end{tabular}

(1) Intrauterine $20 \mathrm{cc}$.

(2) Day $0=$ day of estrus.

(3) All ewes were synchronized using progesterone implants for 14 days and 1000 IU PMS at day of implant removal.

$\left(^{4}\right)$ Intramuscular daily injections.

(5) Endometrium-modified ewes.

(6) Endometrium-intact ewes.

(7) No treatment, endometrium-intact ewes. 
Experiment 4. - A total of 24 ewes was used in this experiment to further elicit the pathway of oxytocin as a luteolytic substance. The ewes were allotted to 3 equal groups as they came into estrus after synchronization. Vasectomized rams were used for estrus detection. Ewes in group 1, serving as controls, received $50 \mathrm{IU}$ of oxylocin from days 1 to 7 of the estrous cycle and were laparotomized on day 10. The ewes in group 2 also received 50 IU of oxytocin from days 1 to 7 and were hysterectomized on day 3 of the cycle. The ewes in the third group were hysterectomized on day 8 and received $25 \mathrm{mg}$ of $\mathrm{PGF}_{2 \alpha^{-}}$tham on day 10 of the estrous cycle. All ewes were autopsied on day 13 of the cycle and the corpora lutea were removed and weighed. Table 4 shows the overall experimental design.

TABLE 4

Experimental design

\begin{tabular}{|c|c|c|c|c|c|}
\hline \multicolumn{2}{|c|}{ Treatment } & \multirow{2}{*}{$\begin{array}{c}\text { Day of } \\
\text { injection (1) }\end{array}$} & \multirow{2}{*}{$\begin{array}{l}\text { Day of } \\
\text { surgery }{ }^{\left({ }^{1}\right)}\end{array}$} & \multirow{2}{*}{$\begin{array}{c}\text { Day of } \\
\text { slaughter (1) }\end{array}$} & \multirow{2}{*}{$\begin{array}{l}\text { No. } \\
\text { ewes }(2)\end{array}$} \\
\hline Injection & Surgery & & & & \\
\hline $\begin{array}{l}\text { Oxytocin } 50 \text { IU }\left({ }^{(3)} \ldots \ldots\right. \\
\text { Oxytocin } 50 \text { IU }{ }^{(3)} \ldots \ldots\end{array}$ & $\begin{array}{l}\text { Laparotomy } \\
\text { Laparotomy and } \\
\text { hysterectomy }\end{array}$ & $\begin{array}{l}1-7 \\
1-7\end{array}$ & $\begin{array}{r}10 \\
3\end{array}$ & $\begin{array}{l}13 \\
13\end{array}$ & $\begin{array}{l}8\left({ }^{5}\right) \\
8(6)\end{array}$ \\
\hline PGF $_{2 \alpha}$-tham $25 \mathrm{mg}\left({ }^{4}\right) \ldots$ & $\begin{array}{l}\text { Laparotomy and } \\
\text { hysterectomy }\end{array}$ & 10 & 8 & 13 & $8\left(^{6}\right)$ \\
\hline
\end{tabular}

(1) Day $0=$ day of estrus.

(2) All ewes were synchronized using progesterone implants for 14 days.

$\left({ }^{3}\right)$ Intramuscularly daily injections.

(4) One intramuscular injection.

$\left({ }^{5}\right)$ Endometrium-intact ewes.

(') Hysterectomized ewes.

The results of all the experiments were statistically analyzed using analysis of variance; the treatments were compared by the Duncan method (Duncan, 1955).

\section{Results.}

Experiment 1. - The effect of exogenous oxytocin on estrous cycle length is presented in figure 1. All the control ewes and 6 of the 8 oxylocin-treated animals during the first (days 1 to 7 ) and the second (days 8 to 14) halves of the estrous cycle had a mean estrous cycle length of 19.8 days (16 to 21 days), which is considered normal for this breed (Karagouniko milking breed), while 2 ewes from group 1 (oxytocin days 1 to 7 ) had an estrous cycle length of 6.0 days and 2 ewes from group 2 (oxytocin days 8 to 14) had an estrous cycle lasting 15 and 24 days, respectively. Although the results of this trial showed no significant reduction of estrous cycle length in oxytocin-treated and control ewes, the 2 ewes of group 1 (oxytocin days 1 to 7 ), in which new estrus was detected 6 days after the initial one, tended to have a shorter estrous cycle. This trend becomes evident when comparing the interestrous periods befween 
the oxytocin-treated ewes during the first half of the cycle (15.13 days) and the oxytocin-treated ewes during the second half of the cycle (18.63 days), as well as the controls (18.75 days).

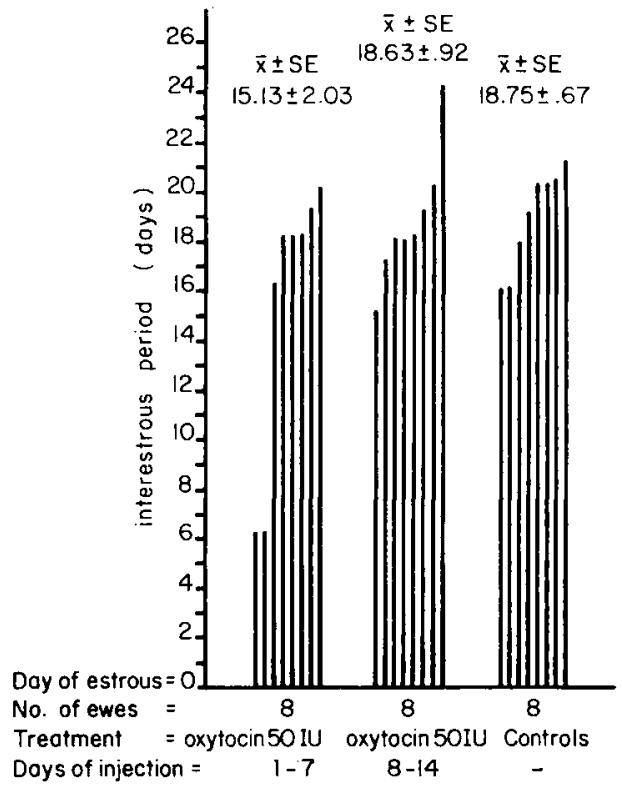

FIG. 1. - The effect of oxytocin on estrous cycle duration in ewes.

Experiment 2. - The luteolytic effect of exogenous oxytocin was evidenced during this experiment, as shown in table 5. The administration of $50 \mathrm{IU}$ of oxytocin daily resulted in a significant $(P<0.05)$ reduction of luteal weight as compared to that of the controls (518.4 \pm 41.4 and $564.6 \pm 49.9$ vs $758.8 \pm 50.7 \mathrm{mg}$ ) on day 14 of the estrous cycle. A tendency for greater luteal reduction was observed when oxyto-

TABLE 5

The effect of exogenous oxyfocin on corpus luteum weight in ewes

\begin{tabular}{|c|c|c|c|}
\hline Treatment & $\begin{array}{l}\text { Days } \\
\text { injected (1) }\end{array}$ & $\begin{array}{l}\text { No. } \\
\text { ewes }\left({ }^{2}\right)\end{array}$ & $\begin{array}{l}\text { Corpus luteum weight } \\
(x \pm \mathrm{SE}, \mathrm{mg})\left(^{3}\right)\end{array}$ \\
\hline $\begin{array}{l}\text { Oxytocin } 50 \text { IU }\left(^{4}\right) \ldots \ldots \\
\text { Oxytocin } 50 \text { IU }\left(^{4}\right) \ldots \ldots \\
\text { Controls }\left(^{5}\right) \ldots \ldots \ldots \ldots\end{array}$ & $\begin{array}{l}1-7 \\
8-14 \\
-\end{array}$ & $\begin{array}{l}10 \\
10 \\
10\end{array}$ & $\begin{array}{l}518.4 \pm 41.4(a) \\
564.6 \pm 49.9(a) \\
758.8 \pm 50.7(b)\end{array}$ \\
\hline
\end{tabular}

(1) Day $0=$ day of estrus.

(2) All ewes were synchronized using progesterone implants for 14 days.

(3) Corpora lutea removed from autopsied ewer at day 14 of estrous cycle.

(4) Intramuscular daily injections.

(5) No treatment. *P $<0.05$ for comparison $a$ to $b$. 
cin was administered during the first half (days 1 to 7) as compared to ewes treated during the second half (days 8 to 14 ) of the estrous cycle (518.4 \pm 41.4 vs 564.6 土 $49.9 \mathrm{mg}$ ).

Experiment 3. - The luteolytic effect of exogenous oxytocin was further confirmed in this experiment by investigating the anatomical degeneration (weight) of the corpora lutea and their functional regression (luteal progesterone content) (Stormshak ef al., 1963). The results of this experiment are summarized in table 6 . Thus, oxytocin demonstrated a significant $(P<0.05)$ luteolytic effect in oxytocin-treated ewes with intact endometrium ( $1594.2 \pm 145.4 \mathrm{mg}$ ) as compared to untreated controls also having an intact endometrium (2 $458.6 \pm 314.6 \mathrm{mg})$. However, the luteolytic property of oxytocin was negated in oxytocin-treated ewes with modified endometrium (2 514.8 $\pm 272.7 \mathrm{mg}$ ), as shown by comparing the oxytocin-treated ewes with intact endometrium $(1594.2 \pm 145.4 \mathrm{mg} ; \mathrm{P}<0.05)$ to the untreated controls with intact endometrium (2 $458.6 \pm 314.6 \mathrm{mg}$ ). The progesterone content of the corpora lutea tended to follow the same patterns as luteal weight. Thus, the corpora lutea from oxylocintreated ewes with intact endometrium had lower progesterone content $(9.55 \pm$ $1.24 \mu \mathrm{g} / \mathrm{mg}$ ) than the corpora lutea from untreated controls with intact endometrium $(13.22 \pm 2.31 \mu \mathrm{g} / \mathrm{mg})$ or from oxylocin-treated ewes with modified endometrium $(11.72 \pm 1.46 \mu \mathrm{g} / \mathrm{mg})$.

TABLE 6

The effect of exogenous oxytocin on corpora lutea in ewes with intact and modified endometrium

\begin{tabular}{|c|c|c|c|c|c|c|}
\hline \multirow[b]{2}{*}{ Treatment } & \multirow[b]{2}{*}{ Days } & \multirow[b]{2}{*}{$\begin{array}{c}\text { No. } \\
\text { ewes }\left({ }^{2}\right)\end{array}$} & \multirow[b]{2}{*}{$\begin{array}{c}\text { State of } \\
\text { endometriu m }\end{array}$} & \multicolumn{3}{|c|}{ Corpora lutea $\left({ }^{3}\right)$} \\
\hline & & & & $\begin{array}{c}\text { Weight } \\
(\bar{x} \pm S E, m g)\end{array}$ & $\begin{array}{c}\text { Progesterone } \\
\text { content } \\
(\overline{\mathbf{x}} \pm \mathrm{SE}, \mathrm{mg})\end{array}$ & $\begin{array}{c}\text { Progesterone } \\
\text { concentration } \\
(\bar{x} \pm S E, \mu g / m g)\end{array}$ \\
\hline $\begin{array}{l}\text { Oxytocin } 50 \text { IU }\left(^{4}\right) \\
\text { Oxytocin } 50 \text { IU }\left(^{4}\right) \\
\text { Controls (5)..... }\end{array}$ & $\begin{array}{l}1-7 \\
1-7 \\
-\end{array}$ & $\begin{array}{l}10 \\
10 \\
10\end{array}$ & $\begin{array}{c}\text { modified }\left({ }^{6}\right) \\
\text { intact }\left({ }^{7}\right) \\
\text { intact }\end{array}$ & $\begin{array}{l}2,514.8 \pm 272.7(a) \\
1,594.2 \pm 145.4(b) \\
2,458.6 \pm 314.6(a)\end{array}$ & $\begin{array}{l}27.07 \pm 5.55 \\
14.14 \pm 3.04 \\
32.23 \pm 10.58\end{array}$ & $\begin{array}{r}11.72 \pm 1.46 \\
9.55 \pm 1.24 \\
13.22 \pm 2.31\end{array}$ \\
\hline
\end{tabular}

(1) Day $0=$ day of estrus.

(2) All ewes were synchronized using progesterone implants for 14 days and 1000 IU PMS on day of implant removal.

(3) Corpora lutea removed from autopsied ewes on day 12 of estrous cycle.

(4) Intramuscular daily injections.

(5) No treatment.

(6) Intrauterine infusion of $20 \mathrm{cc}$ of 10 p. 100 phenol solution at day 2 of estrous cycle.

(7) Intrauterine infusion of $20 \mathrm{cc}$ of physiological saline solution at day 2 of estrous cycle.

* $P<0.05$ for comparison $a$ to $b$ (same column).

Experiment 4. - The luteolytic effect of exogenous oxytocin was tested in hysterectomized ewes to determine the possible route of action of oxytocin as a luteolytic agent. The results of this trial are summarized in table 7 . Thus, the administration of $50 \mathrm{IU}$ of oxytocin from days 1 to 7 of the estrous cycle in ewes with intact uterus resulted in luteolysis, while in hysterectomized ewes the luteolytic property of oxytocin 
was negated $(806.4 \pm 86.8$ vs $1380.0 \pm 189.6 \mathrm{mg} ; P<0.05)$. The substitution of the uterus, the source of the luteolytic agent (Goding, 1974), by $\mathrm{PGF}_{2 \alpha}$-tham caused corpus luteum lysis as compared to hysterectomized ewes (446.1 \pm 112.3 vs $1380.0 \pm$ $189.6 \mathrm{mg} ; P<0.05)$ and to oxytocin-treated ewes with intact uterus $(446.1 \pm 112.3 \mathrm{vs}$ $806.4 \pm 86.8 \mathrm{mg})$.

TABLE 7

The effect of oxytocin and $\mathrm{PGF}_{2 \alpha}$ on corpus luteum in intact and hysferectomized ewes

\begin{tabular}{|c|c|c|c|c|}
\hline Treatment & $\begin{array}{c}\text { Days } \\
\text { injected (1) }\end{array}$ & $\begin{array}{c}\text { Day of } \\
\text { hysterectomy (1) }\end{array}$ & $\begin{array}{c}\text { Corpus luteum } \\
\text { weight } \\
(\bar{x} \pm S E, m g)\end{array}$ & $\begin{array}{l}\text { No. } \\
\text { ewes }\left({ }^{3}\right)\end{array}$ \\
\hline $\begin{array}{l}\text { Oxytocin } 50 \mathrm{IU}\left({ }^{4}\right) \ldots \\
\text { Oxytocin } 50 \text { IU }\left(^{4}\right) \ldots \ldots \\
\text { PGF }_{2 \alpha} \text {-tham } 25 \text { mg }\left({ }^{5}\right) \ldots\end{array}$ & $\begin{array}{r}1-7 \\
1-7 \\
10\end{array}$ & $\begin{array}{l}-\overline{3} \\
8\end{array}$ & $\begin{array}{r}806.4 \pm 86.8 \\
1,380.0 \pm 189.6 \\
446.1 \pm 112.3\end{array}$ & $\begin{array}{l}8 \\
8 \\
8 \\
8\end{array}$ \\
\hline
\end{tabular}

(1) Day $0=$ day of estrus.

( $\left.{ }^{2}\right)$ Corpora lutea removed from autopsied ewes on day 12 of estrous cycle.

(3) All ewes were synchronized using progesterone implants for 14 days.

(4) Intramuscular daily injections.

(5) One intramuscular injection.

\section{Discussion.}

The administration of $50 \mathrm{IU}$ of oxytocin to ewes resulted in corpus luteum regression whether injection was carried out during the first (days 1 to 7 ) or the second (days 8 to 14) half of the estrous cycle. However, a tendency for greater luteal regression was observed when oxytocin was injected during the first half of the cycle. It is somewhat surprising that cycle shortening was observed in only 2 out of 8 ewes. However, a comparable observation was reported by Milne (1963), who found that neither the dosage level of oxytocin $(15$ to $50 \mathrm{IU})$ nor the time of commencement of treatment after estrus ( 1 to 4 days) affected estrous cycle length within the normal limits of 14 to 19 days in 7 ewes of the Merino breed, although the corpora lutea on day 8 of the cycle appeared to be degenerate upon histological examination. Contrary to this report, Dobrowolski (1973) observed that $50 \mathrm{IU}$ of oxytocin injected on days 3 to 5 of the cycle in 11 Merino ewes shortened the estrous cycle by $0.96 \pm 0.21$ days; this was regarded as significant. Experiments in cows treated with oxytocin during the first halft of the cycle demonstrated evident luteal regression (Armstrong and Ha nsel, 1959 ; Harms and Malven, 1969 ; Auletta ef al., 1972), although the estrous cycle length was sometimes normal (Simmons and Hansel, 1964). The explanation of the normal estrous cycle length with regressed corpora lutea in cattle was that luteal progesterone concentration was higher than the critical level $(20 \mu \mathrm{g} / \mathrm{mg})$, below which the cows showed precocious estrus (Simmons and Hansel, 1964). Therefore, it seems possible that precocious estrus in oxytocin-treated ewes could be related to the degree of luteal regression. 
There may be several modes of oxytocin action responsible for luteal regression when a high dose of the hormone (50 IU) is administered. However, the fact that oxytocin loses its luteolytic effect in endometrium-modified ewes or in hysterectomized ewes strongly suggests that the pharmacological dose of this hormone exerts its luteolytic action through the endometrium, probably by influencing the synthesis and/or the release of uterine luteolytic agent, rather than directly on the ovary and/or the hypothalamo-pituitary axis. This is in agreement with recent reports by Sharma and Fitzpatrick (1974) and Roberts ef al. (1975) showing that exogenous oxytocin in ewes caused a pronounced release of $\mathrm{PGF}_{2 \alpha}$ from the uterus. Recently, Chan (1977) demonstrated that exogenous oxytocin induces enhanced PG synthesis and release from the non-pregnant as well as from the parturient uterus of rats. Moreover, the amount of released $\mathrm{PGF}_{2 \alpha}$ appeared to depend more on the priming dose of estrogen, which sensitizes the uterus to oxytocin action, than on the challenging dose of oxytocin. Further experiments in cows (Newcomb, 1977) indicate that the release of PGF from the uterus, after oxytocin treatment, is not the result of myometrial contractions, but that it might be of metabolic origin (such as synthesis from precursors) because of the prolonged release of PGF from the uterus after a single oxytocin infusion.

\section{Conclusions.}

The conclusions draw from the results of the present study are the following : 1. the administration of $50 \mathrm{IU}$ of oxytocin daily does not seem to apparently decrease the length of the estrous cycle in milking ewes;

2. the administration of $50 \mathrm{IU}$ of oxytocin daily from days 1 to 7 or from days 8 to 14 results, however, in luteal regression, appraised from the reduction of luteal weight and luteal progesterone content;

3. endometrial destruction or uterine ablation negates the luteolytic effect of exogenous oxytocin.

The last conclusion strongly supports the hypothesis that the luteolytic effect of an exogenous pharmacological dose of oxytocin is exerted through the uterineovarian axis, probably by inducing synthesis and /or release of the uterine luteolytic agent from the endometrium.

Reçu en mars 1978.

Accepté en octobre 1978.

Acknowledgments. - The authors are grateful to Dr. W. C. Foote, Professor of Animal Science, Utah State University, Logan, 84322, Utah, USA, for performing the RIA of progesterone. PGF PGx $_{2 x}$ tham was generously supplied by Dr. J. W. Lauderdale, Upjohn Co., Kalamazoo, Michigan, 49001, USA.

Résumé. Nous avons étudié l'effet de l'ocytocine exogène sur la longueur du cycle estrien et la lyse du corps jaune, en utilisant 111 brebis au cours de 4 expériences. L'expérience 1 montre que la longueur du cycle estrien n'est pas réduite significativement dans le lot des animaux traités à l'ocytocine ; cependant, 2 sur 8 présentèrent un nouvel estrus 6 jours après le premier. L'expérience 2 montre clairement $(p<0,05$ la propriété lutéolytique de $50 \mathrm{UI}$ d'ocytocine si on les administre du $1^{\mathrm{er}}$ au $7 \mathrm{e}$ jour du cycle. Les expériences 
3 et 4 montrent que la destruction de l'endomètre ou l'ablation de l'utérus annulent la propriété lutéolyrique de l'ocytocine. On peut conclure que l'administration quotidienne de $50 \mathrm{UI}$ du $1 \mathrm{er}$ au $7 \mathrm{e}$ jour du cycle entraîne la lyse du corps jaune chez les brebis et que l'action lutéolytique de l'ocytocine s'exerce par l'endomètre.

\section{References}

ALIFAKIOTIS T., 1973. Studies on corpus luteum function in sheep. Utah State Univ., Logan, Utah, U.S.A. Ph. D : Thesis.

ALIFAKIOTIS T. A., 1977. The effects of estradiol-17 $\beta$, progesterone, and $\mathrm{PGF}_{2^{\mathrm{a}}}$-tham on corpora lutea in ewes with intact and partially destroyed endometrium. Theriogenology, 7, 293-301.

ANDERSON L. L., BOWERMAN A. M., MELAMPY R. M., 1965. Oxytocin on ovarian function in cycling and hysterectomized heifers. J. anim. Sci., 24, 964-968.

ARMSTRONG D. T., HANSEL W., 1959. Alteration of the bovine estrous cycle with oxytocin. J. Dairy Sci., 42, 533-542.

AULETTA F. J., CURRIE G. N., BLACK D. L., 1972. Effect of oxytocin and adrenergic drugs on bovine reproduction. Acta endocr., 69, 241-248.

BLACK D. L., DUBY R. T., 1965. Effect of oxytocin, epinephrine and atropine on the cestrous cycle of the cow. J. Reprod. Fert., 9, 3-8.

CAMEROUN N. W., FOSGATE O. T., 1964. Effects of oxytocin upon the reproductive tract of the lactating bovine. J. Dairy Sci., 47, 79-81.

CARLSON J., BLACK D. L., 1969. Oxytocin produced changes in the bovine ovary before and after unilateral ovariectomy. J. Reprod. Fert., 20, 39-43.

CHAN Y. W., 1977. Relationship between the uterotonic action of oxytocin and prostaglandins : Oxytocin action and release of PG-activity in isolated nonpregnant and pregnant rat uteri. Biol. Reprod., 17, 541-548.

DOBROWOLSKI W., 1973. The effect of oxytocin on the duration of ovine estrous cycle in breeding and anestrus season. Pol. Archiw. Weier., 16, 649-654.

DONALDSON L. E., HANSEL W., VAN VLECK L. D., 1965. Luteotropic properties of luteinizing hormone and nature of oxytocin induced luteal inhibition in cattle. J. Dairy Sci., 48, 331-337.

DONALDSON L. E., TAKKEN A., 1968. The effect of exogenous oxytocin on corpus luteum function in the cow. J. Reprod. Fert., 17, 373-383.

DONALDSON L. E., 1969. Effect of continued daily injections of oxytocin on œestrous cycle length and reproductive tract morphology in the cow. J. Reprod. Fert., 18, 259-263.

DUNCAN D. B., 1955. Multiple range and multiple $F$ tests. Biometrics, 11, 1-42.

EDQVIST S., EINARSSON S., GUSTAFSSON B., LINDE C., LINDELL J. O., 1975. The in vitro and in vivo effects of prostaglandins $E_{1}$ and $E_{2 a}$ and of oxylocin on the tubular genital tract of ewes. Int. J. Fertil., 20, 234-238.

FOOTE W. C., ALIFAKIOTIS T. A., CALL J. W., 1974. Functioning relationship between endometrium and corpus luteum in the ewe. J. anim. Sci., 39, 207 (abstr.).

GINTHER O. J., WOODY C. O., MAHAJAN S., JANAKIRAMAN K., CASIDA L. E., 1967. Effect of oxylocin administration on the œstrus cycle of unilaterally hysterectomized heifers. J. Reprod. Fert., 14, 225-229.

GODING J. R., 1974. The demonstration that $\mathrm{PGF}_{2 \mathrm{a}}$ is the uterine luteolysin in the ewe. J. Reprod. Feri., 38, 261-271.

HANSEL W., 1959. Further studies on the regulation of the bovine estrous cycle by oxytocin injections. J. Dairy Sci., 42, 940-941 (abstr.).

HANSEL W., WAGNER W. C., 1960. Luteal inhibition in the bovine as a result of oxytocin injections, uterine dilatation and intrauterine infusions of seminal and prepuriat fluids. J. Dairy Sci., 43, 796-805.

HARMS P. G., MALVEN P. V., 1969. Modification of bovine luteal function by exogenous oxytocin and progesterone. J. anim. Sci., 29, 25-29.

HOPPE R., KARCZEWSKI W., JEDRUCH J., 1969. The effect of oxytocin on the cestrus cycle and fertility in heifers and cows. Medyc. Weter., 25, 165-167. 
LABHSETWAR A. P., COLLINS W. E., TYLER W. J., CASIDA L. E., 1964. Effect of progesterone and oxytocin in the pituitary ovarian relationship in heifers. J. Reprod. Fert., 8, 77-83.

LOUIS T. M., KITTOK R. J., 1973. Extraction and radioimmunoassay of progesterone. Michigan State Univ. (Unpublished data).

LYNN J. E., COLLINS W. E., INSKEEP E. K., MCSHAN W. H., CASIDA L. E., 1965. Effects of gonadotropins, oxytocin and glucose on the bovine corpus luteum at the fourteenth day of the estrual cycle. J. anim. Sci., 24, 790-794.

MCCRACKEN J. A., CARLSON J. C., GLEW M. E., GODING J. R., BAIRD D. T., 1972. Prostaglandin $F_{2 \mathrm{a}}$ identified as a luteolytic hormone in sheep. Nature New Biol., 238, 129-134.

MILNE J. A., 1963. Effects of oxytocin on the œstrous cycle of the ewe. Austr. Vet. J., 39, 51-52.

MILVAE R. A., HIXON J. E., HANSEL W., 1976. Progesterone and LH in oxytocin treated heifers. J. anim. Sci., 43, 297 (abstr.).

NEWCOMB R., BOOTH D. W., ROWSON L. E. A., 1977.The effect of oxytocin treatment on the level of prostaglandin $F$ in the blood of heifers. J. Reprod. Fert., 49, 17-24.

RAESIDE J. I., 1958. Effect of oxytocin, prolactin and human chorionic gonadotropin on the estrous cycle in the ewe. J. anim. Sci., 17, 1231 (abstr.).

ROBERTS J. S., BARCIKOWSKI B., WILSON R., SCARNES G. R., MCCRACKEN J. A., 1975. Hormonal and related factors affecting the release of prostaglandin $F_{2 \mathrm{a}}$ from the uterus. $J$. Steroid Bioch., 6, 1091-97.

SHARMA S. C., FITZPATRICK R. J., 1974. Effect of œstradiol-17 $\beta$ and oxytocin treatment of prostaglandin $\mathrm{F}$ alpha release in the anœstrous ewes. Prostaglandins, 6, 97-105.

SIMMONS K. R., HANSEL W., 1964. Nature of the luteotropic hormone in the bovine. J. anim. Sci., 23, 136-141.

STORMSHAK F., INSKEEP E. K., LYNN J. E., POPE A. L., CASIDA L. E., 1963. Progesterone levels in corpora lutea and ovarian effluent blood of the ewe. J. anim. Sci., 22, 1021-26.

SVEJDA A. J., FOOTE W. C., 1973. Extraction and radioimmunoassay of progesterone. Utah State Univ., Logan, Utah, U. S. A. (personal communication). 